\title{
A Feminist Critical Discourse Analysis of Qaisra Shahraz's The Holy Woman in the Backdrop of Subalternity
}

\author{
Hadia Khan ${ }^{1}$ \\ ${ }^{1}$ Lecturer in Mechanical Engineering Department, HITEC University, Taxila, Pakistan \\ Correspondence: Hadia Khan, Lecturer in Mechanical Engineering Department, HITEC University, Taxila, \\ Pakistan. E-mail: hadia.khan0888@yahoo.com
}

\author{
Received: May 29, 2019 Accepted: July 6, 2019 Online Published: August 26, 2019 \\ doi:10.5539/ijel.v9n5p249 URL: https://doi.org/10.5539/ijel.v9n5p249
}

\begin{abstract}
This paper analyzes the objectification of the South Asian female subject as subaltern by the patriarchal power structure, and disrupts the relevant discourse practices. It investigates this notion in Qaisra Shahraz's novel The Holy Woman. Methodologically, it applies Gayatri Spivak's perspective of the subaltern to establish its ontological premise. Additionally, it uses Lazar's concept of Feminist Critical Discourse Analysis to deconstruct the power discourse behind the objectification of the female identity as reflected in the selected text. The analysis of the selected text reflects as the South Asian patriarchal society 'legitimizes' the 'othering' of its female subject for the fulfilment of its power agenda that involve political and economic interests. The analysis also reveals as dominant discourse interprets religion the way it suits the power structure. It also shows how the female subject realizes its manipulation by acquiring the knowledge which she earlier lacked and on the acquired awareness, resists the power structure. Through its methodological approach, the paper incites further research into the reorientation of subalternity in the South Asian context.
\end{abstract}

Keywords: subalternity, Feminist Critical Discourse Analysis, Power structure, female identity.

\section{Introduction}

The concept of subalternity, as originally propounded by Gayatri Spivak defines the "oppressed subject" as a group politically and socially encircled in hegemonic power structures and that is segregated within the established structures and excluded from political representation. The discussion which initially started within the umbrella of postcolonial discussion, culminated into a specific area of separate subaltern studies (Nelson \& Grossberg, 1988, p. 295). Spivak's question 'can the subaltern speak?' rhetorically refers to the silence of the female subject that has faced over history. Spivak's notion of subalternity is linked with Antonio Gramsci's concept of the inferior. However, Spivak focuses on the female subaltern and the 'struggles' of this class to resist the power and hegemony of the controlling domestic patriarchal circle that weakens it and further decimates its identity to bring silence. She thinks that the subaltern is the woman, not the peasants, as they cannot raise their voices for their legal rights.

The theorization of the subaltern identity of the other has depended on relevant rhetoric and discourse. Critical Discourse Analysis that views language in power ideology and agenda exposes the power structure that is pedestaled discursively. Specifically, in this context from Lazar the roots go back to Foucault and Derrida. However, this idea goes back to its theorization, which is possible through gender discourse analysis and conditions surrounding the subaltern. This leads to feminist discourse analysis as Michelle M. Lazar in her book, "Feminist Critical Discourse Analysis: Gender, Power and Ideology in Discourse" (2005) argues that the aim of feminist critical discourse (FCDA) is to demonstrate discursive production and gender analysis to interpret human psychology (p. 11). In fact, the text is subject to multidimensional analysis on account of impact economic, social, political and cultural factors. FCDA is interdisciplinary and deals with the "patriarchal society on the core structure of power relationship that privilege men and disempowered women from the social setup" (p. 5). Hence, its objective is to interlink gender discourse in a text to deal with its representation in the social and cultural contexts. On the one side, it analyzes language and discourse from a feministic viewpoint, and on the other side, it traces feministic issues through discourse. Spivak is another gender-specific writer having a unique critique of the issue with reference to the feminine subaltern. 
The subaltern subject has incurred much discussion on the South Asian society. Qaisra Shahraz, a Pakistani English writer, highlights the Pakistani feudal-cum-patriarchal system, where an educated female is forced to stay in a confined environment. Asian femininity is silenced with the traditional conceptual framework of " $i z z a t$ " (Note 1). This group is not allowed to raise voice against familial patriarchal circle. Shahraz deals with the feminist issues, discussing these problems and hegemony of the dominating structure that suppresses its identity. The rural part of Sindh, one of the four provinces of Pakistan, becomes experimental ground for the setting of her novel, The Holy Woman (2001). The story of the text revolves around an educated female character named Zarri Bano, and she has to follow the ritual of marrying to the Holy Quran after the death of her only brother. The story is about feudal lords, the way they feel themselves superior and all other people as inferior objects including their own women at home. The main plot revolves around Zarri, an educated modern girl of new era, but sub-plot deals with the village life, the women representing lower class such as Firdous, Kulsoom Ji, Sardara and Naimat Bibi. These women work hard to earn for their living.

\subsection{Research Objective}

i. To find out the way the patriarchy as depicted in Qaisra Shahraz's The Holy Woman constitutes the female identity and exploits it because of its discourse practices.

\subsection{Research Question}

i. How does the patriarchal power structure discursively 'legitimize' the female identity and use the objectification of this identity for its agenda?

\subsection{Subalternity}

The term 'subaltern' has witnessed varied meanings. In the book, Gayatri Chakravorty Spivak, Stephen Morton states that subaltern historians amalgamate their work with post-modernist school of thought, borrowing the idea of power relations postulated by Foucault. Spivak seems critical of this knowledge/power Foucauldian model because it ignores the exploitation of the 'third world' workers both inside and outside home. Spivak refers to Michel Foucault and Gilles Deleuze who consider it a heterogonous relationship among power/desire/interest, as it is counter-productive to reducing legitimacy of network. Secondly, both consider intellectuals to play a role of discourse as a medium in the othering. Referring to these critics, Spivak adds that "theory is a relay of practice" and that the oppressed can speak for themselves. She (2003) argues that this concept of "speaking for themselves," questions representation and self-representation (p. 57). She (1988) is of the view that Deleuze and Foucault fail to recognize the process of reproduction of a system that silences Europe's 'Other'. According to her, they are unaware of "what actually happens" as Foucault insists on "speaking for themselves" when he terms the oppressed as "subject," the "object being" knows better than the intellectual does and they can speak it well (Nelson \& Grossberg, p. 274). They discuss margins, the silenced centre, the tribal, the illiterate peasantry and the lower strata of urban sub-proletariat. Bell Hooks (1989) reviews the subaltern's awareness of those silencing forces to state that these forces differ from the forces that want the subaltern to speak. The critic thinks that these forces, which seem to push the subaltern to speak, primarily want them to speak from the space in the margin, and not in the voice of resistance. Hence, space in margin is the sign of deprivation and unfulfilled longing. She then affirms "marginality as a site of resistance" (p. 209).

Spivak further argues about its 'Marxist' nature with difference in its historiography. In "Deconstructing Historiography", she does not link it with Marxism but questions subaltern consciousness and subalternity. She tries to split subaltern into a group that survives in a hegemonic structure. It means that to know the marginalized and suppressed by colonial and nationalist historians the subaltern critics have used post-structuralist and deconstructive strategies. Dipesh Chakrabarty (2000) argues that the past of subaltern is taken as the past of the historians. She states it the Indian context that "violence and hierarchy that sustain remain the dominant organizing principles in everyday life whereas West is characterized by individualism, democracy and egalitarianism" (Chaturvedi 56).

However, she states that "colonial S/subject" as a philosophical agent, and the politics of representation as a problem. For her, the notion of "self/other" is a colonial ideology for colonies to which European calls "other" (p. 56). Thus, for Spivak, the European's act of essentialization of the 'other' is 'reinforcement of imperial ideology' and an "epistemic violence." J. Maggio (2007) observes referring to Kantian theoretical lens that only European man can survive, excluding subaltern from the "subject" to establish the modern western subject that helps to define its otherness. Therefore, silencing of the subaltern does not only shape the discourse but also renders the subaltern without a "subject being" (p. 426). 


\subsection{Subalternity and Feminist Critical Discourse Analysis}

The power structure has always depended on discourse to constitute and exploit the identity of "othering". As discourse is socially constructed and depends upon the complexities in relationship on the way social relations are exercised and the social identities are revealed through particular discourse (Fairclough, 1995). This research shows that discourse analysis helps understand the vantage point of a female as a complex ongoing process influenced by the dominant forces in surroundings such as marriage, violence, family setup, sexuality, social pressure and other assumptions that bind them to live in that contested world. Subsequently, Lazar's (2005) argument of feministic perspective in the textual discourse shows that interest lies on the "re-presentation" of gender and their power relations in the particular texts and contexts (p. 11). According to feminist critical discourse analysis, discourse is considered one element of social practices having a dialectal relationship between discourse and society. In this connection, Penelope Eckert and Sally McConnell Ginet (2003) discuss the complex relationship of gender order in the following words, "The gender order is on a system that is allocation, divided between rights and obligations, limits and possibilities, freedom and constraints, power and subordination. This structure is supported by and supports structures of convention, emotion, ideology and desire" (p. 34).

This perspective stipulates the notions of power and ideology interconnected and inseparable from power and gender. This process of 'allocation' is structured to gain various benefits such as feminine 'otherness' to make it an object of sympathy. These structures changing it into conventions and norms show it amply that people stick to them thinking as cannons. Thus, the social power structures exert control over the discourse that not only supports them but also supports the ideological framework made by these power structures. The intention of FCDA is to transform society and provide social justice to the members, for all genders are the pillars of society having equality in responsibilities and duties.

Here feminist CDA highlights the complex, elusive and taken-for-granted gendered assumptions and hegemonic power relations including the challenges to them in different contexts. The women develop their inner strength to overcome dominant forces. Therefore, feminist CDA does not have any emancipatory agenda; rather, it is a 'transformative quest' that gives voice to the marginalized, suppressed and silenced voices. It seems that femininity has been reduced to a figure to be examined that Chandra Mohanty has termed as a "monolithic signifier", and handwork of the western feminist scholars in his book, Feminist Postcolonial Theory; A Reader (2003). She stipulates analytical strategies, rules and principles combined to present the third world woman as a helpless victim. The western feminists point out the family structure a cause of gender oppression and ignore social and historical changes taking place. She includes Islamic ideology and its attendant features such as purdah (Note 2), she quotes Mina Modares that Islamic impacts woman regardless of their positions (p. 62). Responding to these accusations Marnia Lazreg (1988) argues that women live in a non-historical time with no change. The presupposition of the sameness of the feministic oppression leaves other pointers of class, race and ethnicity; she says adding such differences cannot be overlooked in these surroundings, for the followers of a particular religion cannot be treated as the same entity across cultures. She exemplifies this through her description of the practice of Iranian veil that is a historical reality and not a religious duty. Jasmine Zine (2006) terms it a legal force instead of it being a religious symbol such as in Saudi Arabia and Iran and none in democratic societies such as Turkey (p. 11). Analyzed through the lens of FCDA, the case of The Holy Woman by Shahraz in this scenario not only demonstrates feminine subalternity but also feministic resistance, FCDA's elements.

\section{Methodology}

This study is qualitative content analysis. Theoretically, it applies Gayatri Spivak's notion of subalternity and feminist critical discourse analysis for the textual analysis of Qaisra Shahraz's The Holy Woman. Moreover, it aligns these perspectives under theoretical triangulation, which encourages qualitative research to examine a question from manifold views to strengthen research findings. Contextually, the alignment of these perspectives suits this study because the critique of subalternity raises concern about the power structure's legitimization of the female othering, whereas feminist critical discourse analysis disrupts the pertinent discourse practices that help the agenda of the powerful. The study specifically focuses on Lazar's concept of Feminist Critical Discourse Analysis.

\section{Discussion}

\subsection{The 'Subaltern' Discourse}

Qaisra Shahraz's female characters face troubles, agonies, dejections, insecurities and fears. A puppet in their patriarchal circles, femininity or femaleness sees marriages virtual prisons in the situation under the static patriarchal formed rules and laws. Feminine criminality faces suppression or, in some cases, outright death. Zarri 
Bano, female protagonist, evinces true figure of an exploited subalternity. Shahraz also frequently disrupts the discourse that the patriarchy has associated with the female subaltern. For example, in the context of the traditional web of comprising marriage, she brings to the limelight the rhetoric such as 'izzat' and 'ghairat' (Note 3 ). These expressions are seemingly neutral; however, they help in constituting a female othering as desired by the patriarchy. Moreover, the words are also important contextually concerning their provocation of the ego of the patriarchs.

Shahraz's novel also significantly offers signs and symbols that are important parts of discourse. For example, she has made use of burqa (Note 4), which is a cultural identity. However, Shahraz has thought it as a prison for her female subject. For example, she says that her protagonist feels 'imprisoned' as she covers her face and body in long black veil (called 'burqa' in Urdu). Moreover, Shahraz refers to the term "holy woman" which the patriarchy exploits to manipulate the protagonist. The protagonist (Zarri) is forced to marry Sikander and when she agrees, she is labeled as 'Holy Woman'. According to Shahraz, any good identity depends on one's conformity to the patriarchal structure of feudalism. Her father feared, in case of the girl's marriage, the son-in-law would inherit his land damaging feudalism. The worldly female figure of Shahraz's protagonist was rather dominating as an independent woman, for her awareness of female rights does not allow her caught in the traditional web. She clears it to her sister Ruby, "I am not a fish to be angled at, caught and trapped, Ruby" (p. 16). However, she is short of choice. Ali Ahmad Kharal, in an article titled "The Holy Woman: The Feminist Perspective", laments that in today's modern world 'the reality is that any religion or any law of the land do not allow these male-made laws to sacrifice females and their basic rights in the name of so-called family honor since the time immemorial' (p. 53).

Naghmana, forcefully divorced by baba Siraj Din, another female character in the novel, undergoes a similar dilemma. A past full of humiliation, fear and insecurity makes her a psychological patient unable to bear insults. An ill-fated event in her teen years spoils Chaudharani Kaniz's peace of mind that has made her stay nervous, guilty and ashamed. After her marriage with a rich man, she becomes haughty and arrogant, yet goes 'begging' the hand of Firdaus (a washerwoman's daughter) to bring back her son. Her apparent sourness and egoism are cloaks to her true self. She never forgets her past molestation and rejection. The world can call her cruel, cross and acidic, yet deep inside, she is shattered and broken.

\subsection{Subalternity and Class Distinction}

Class distinction complements the plight of subalternity. Women in this backdrop seem specific subjects. Gender discrimination is running rampant specifically in lower strata. Not only the women have to earn their living such as Kulsoom Jee, Sardara and Naimat Bibi, but also they are points for change such as Fatima. She accepts a house cleaner's job at Habib Khan's with the objective to educate her daughter. The arrival and subsequent appointment of Firdaus as the principal of the school further redeem her. Firdaus humble background and long struggle give her self-esteem and her subsequent love with Chaudhrani Kaniz's only son makes her bold enough to refuse the offer to pay him back for saying 'washerwoman's daughter' in the past. If the very roots of the authoritarian feudal classes are to be shaken, such young women like Firdaus are required.

In another incident when Fatima comes to visit her daughter, Chaudharani Kaniz snorts in disgust when she sees her coming out of a car (p. 97). If Firdaus and her mother symbolize the lower strata, Chaudhrani Kaniz represents the rich hegemonic structure. Not realizing that the times have changed, she still believes that her 'lower subjects' are there just to obey her. The final reconciliation between Chaudharani Kaniz and Firdaus is a positive sign, showing subaltern unity against patriarchal setup. However, this unity does not end subaltern suffering, for there is a contrast in subaltern too. Zarri and Firdaus are cases in point. Both are educated, young and enthusiastic yet Zarri represents the elite as she succumbs to her father's patriarchal pressure. Firdaus, despite belonging to true subaltern, has the strength to resist this setup. From the feminist perspective, Zarri appears to enjoy freedom though she seems a subaltern caged whose fate is in patriarchal hands. Firdaus, too, exhibits the same thing when confronted by patriarchal circle in the shape of Sikander. Refusing to accept class distinction, Khawar (Chaudhrani Kaniz's son) takes the hand of a housekeeper's daughter in marriage, while Younus Raees marries Chaudharani Kaniz despite having 'a shameful past'. However, Baba Siraj Din and Habib represent patriarchal power structure. Shahraz hopes to end traditions when she shows Baba repenting on his deathbed.

Some female characters such as Naimat Bibi and Kulsoom Jee including Sardara are not only strong but also very assertive. Despite this dominance of the femininity in household and other works, moral framework always supports patriarchy through religion and social traditions. The divorce to Naghmana points to this patriarchal dominance. Feudal system's patriarchal circle and its nature have been shown by Shahraz through such characters. Opposite gender's resistance, outspokenness and protesting behavior further intensify their brutalizing nature. Therefore, Zuleikha, baba Siraj Din's wife who has taken enforced divorce and becomes icons of resistance in her 
village for standing up to the patriarchal power structure that plays its own politics for keeping subalternity in subjugation.

\subsection{Subalternity, Feminist Critical Discourse Analysis, and Power Politics}

Feminist Critical Discourse Analysis focuses on the disruption of power abuse and its impact on the lives of subaltern. Shahraz's novel also touches upon the theme of this power politics that is manifested in various characters. Patriarchy has a complete control not only over how to wield power but also over the institutions dispensing power. This power abuse is brought to the limelight through these characters themselves. For example, women like Zarri's mother often blame their men for crises and disasters in the family. Zarri's mother blames her husband and her husband's father for the disaster befallen on her daughter. As a mother she resisted and stand for her daughter but Habib Khan threaten her with divorce, thus she was forcefully muted. Femininity is accusing patriarchy if nothing is to be done earlier. Zarri says, "What choice do I have?" (p. 71). This apathetic attitude gives clue to the power politics.

The power politics even dominate the domestic environment where its protectorate patriarchy applies it in the shape of "ressmeh" (Note 5) (p. 71). For example, when caught in the web of the feudal culture, Zarri could not help her destined transition from a free woman of the world into a plaything in her father's hands. Seeing her appeals entirely wasted, she submits herself at the altar patriarchy. On her way to become a 'holy woman', she does not even believe all this could happen to her. Her former self dies that day. That moment made her 'dehumanized'. In Shahraz's words, her new role actually makes her deprived of her real identity (p. 144). Shahraz is critical of the assumed traditional gender roles and their subaltern position in a society. She resents that women are subjected to patriarchal violence. This happens in the patriarchal web of religion and tradition used for political power. The concept of forced marriages in the rural areas of the country is a case in point. If a woman silently accepts her fate, she is termed 'good', 'obedient' and 'chaste'. In the case of a possible rebellion, however, there is no escape for the unfortunate girl from brutal (both mental and physical), and a series of other exploitative moves for her. This shows the power of politics played by the patriarchy that leaves the women to subaltern status.

Zarri and Naghmana are dealt unfairly in this power game. They humbly accept all the cruel afflictions, show patience and manage to defeat the harsh destiny. Zarri is unfortunate when her brother Jaffer leaves. Had he been alive, she could have led a normal life. It means only patriarchy can enable subalternity to turn the table of power. In the typical feudal mindset, her father endears land he inherited from his ancestors. He has only two ways before him: marry off his only daughter and lose his land or force her to remain single and keep all the land to himself that is the game of power. He chooses the latter turning his only child to become a 'holy woman,' to grab power. This is how religion and tradition are formed, used and exploited in this power politics. The oppression ends when Zarri ties the knot with Sikander. This clearly shows the suppressed subalternity in the patriarchal web and its loss of power in the power circle weaved by the same patriarchy.

\subsection{Subalternity, Feminist Critical Discourse Analysis, and Identity}

Feminist Critical Discourse Analysis primarily analyzes critically the formation of identity such as othering and its exploitation by the power structure. FCDA specifically focuses on power structure's objectification of women in society. Shahraz's The Holy Woman significantly discusses the objectification of women in Pakistani patriarchal society where all the privileges of decision-making and power structuring are enjoyed by men. Women, on the contrary, are always treated as objects having no identity. There is no recognition of a woman whatsoever. A woman can be a body but never an individual having her own voice, wishes and ways with life. She must entrust herself to the domestic patriarchy. Therefore, girls are supposed lesser human beings having no rights and consequently no identity. The issue of gender discrimination and the young girls' constant exploitation in the patriarchal structure, therefore, becomes a norm. Especially when it comes to marriage, their wishes are never given voice. While making such serious decisions concerning a girl's entire future life, she herself is simply sidelined. As Siraj-Din assures Shahzada about the customs and izzat of their family in the gesture of insult, he states, "But I must be allowed to say that my clan had not yet had the misfortune to become so outrageously 'advance', so morally corrupt" (pp. 36-37). This shows the place of a woman in this patriarchal society where she has no identity. Only education can give her identity but then social norms and religious teachings again relegate her to back, distorting her identity.

Shahraz gives detailed depiction of this distortion. She also shows that tradition and religion are in a continuous struggle. The religious teachings appear to lose ground before the traditions. If the Western scholars are skeptic about Islam and the Shariah (Note 6), it is due to the misinterpretation of religious values. Shahraz unmasks these un-Islamic practices. Zarri is not a rebel, Shahraz shows that as an educated girl, she knows her rights and place but she is forced to become what she does not want and religion does not allow her to be. She later travels across Cairo 
do her much service in terms of increasing her religious knowledge further. Shahraz is clear that the modern education and religion give awareness to subalternity about identity that is stolen by this patriarchal set up. Although Zarri represents local, national, regional, international and universal figure simultaneously, it might not have been the author's original aim to picture her in such dynamic and diverse colors as she seems representing the entire female class that encounters violence at the hands of her domestic patriarchal structure. The girls, supposedly the 'weaker sex', find themselves at the receiving ends and face systematic deprivation from all of their basic rights and final elimination of identity.

\subsection{Subalternity, Feminist Critical Discourse Analysis, and Gender Dominance}

Qaisra's novel reflects that women in the South Asian region is subject to the most grievous 'tyrannies' imposed on them through social traditions under the guise of religion. Shahraz refers to this exploitation of religion by suggesting that the patriarchal structure wrongly legitimizes the oppression of women's rights through the misinterpretation of relevant religious values. According to her, the power structure has adapted religious value the way these values suit its agenda. For example, Zarri's reply to her mother shows that she understands how she is a holy woman as she says, "I found I was reluctant to disillusion them and turn them away from their inner belief that my prayers could help them" (p. 232). Her concept seems to delude even the author whether she knows or not, but equating herself with other women, Zarri seems merging with the subalternity of the South Asian context that the author has clearly shown. However, her awareness of her rights as being the only sister of Jaffer having significance in her patriarchal circle makes her stand apart from other women of her circle. Her father subjects her to downright subalternity having no rights whatsoever merely for his land. This is a prime example of the suppression by the patriarchal circle. From Spivak's viewpoint, Zarri was none of those subalterns who could not speak though she was one of the most outspoken young girls of her generations and known for her feminist stance. When the patriarchal circle surrounds her, she resists saying, "I want to be a normal woman and live a normal life" (p. 85). Here her conversation sheds light on the plight of subaltern of South Asia.

However, this representation stays incomplete without pointing out the patriarchal powers. Explaining the nature and extent of the patriarchal powers in Pakistan, Zarri tells Sikander about their traditions (p. 126). Regardless of her prominent past, her helplessness in the face of the changing circumstances is manifest when she makes this humble admission of her refusal to her father. (p. 173). She identifies herself as she argues that she wants to live and does not invite death. She being a religious scholar response to Jane about addiction of veil that is a clear indication of her representation (p. 184) which is also an assertion that "We women are just small beads in the tapestries of our clans, cleverly woven by our fathers and other male members" (p. 176). It is also significant that though Zarri proves representation of South Asian subalternity, she also exposes western anti-Islam propaganda showing that this is a social construction rather than a religious fiat. The situation of Zarri, Ruby and other female characters show the plight women faces in South Asia merely because of the patriarchal power structure around them does not allow living a full life. However, here Shahraz presents patriarchal misuse of religion and women's representation of the South Asian subalternity as Shahzada speaks out, "For only a really stupid woman would have let her daughter go through that pantomime of a ceremony" (p. 161).

Moreover, Shahraz's subalternity also enjoys a significant resilience to rise up amid oppression. Additionally, there silence that her female subaltern enjoys owes its strength to religion itself. Although it seems that she becomes a native informant as she is engaged in cultural epistemic production for the western audience, she still presents a feminine perspective to give space to subaltern groups.

\section{Conclusion}

Qaisra Shahraz's The Holy Woman reflects the plight of subalternity. This plight is resulted from the objectification of the female subaltern by the patriarchal system. The novel especially focuses the way the power structure exploits its discourse practices to establish a desired identity of women and maintain it. A common rhetoric includes expressions such as holy woman izzat, ghairat, purdah, burqa. The novel emphasizes that these identities are being used and maintained for the promotion of the patriarchal agenda, and not in the sense, the religion promotes them. For example, the ghairat, a discourse feature, commonly provokes the false ego of the men of the society, which has nothing to do with the essence of the religion. In this connection, Zarri is an epitome of subalternity, a holy woman, who not only shows the oppression of her father but also discrimination as being a girl and suffers in the patriarchal web woven through patriarchal social traditions under the guise of religion. She also loses her identity as the only daughter of her father and becomes a holy woman despite knowing that she is not holy or that holiness has not descended upon her. Shahraz's deconstruction of this power discourse that objectifies and then segregates women in the Pakistani context presents the artificial religious and social web that the patriarchy has woven to suppress the feministic subalternity. It also shows that it uses every tactic to keep its 
dominance such as the purchase of land and the transformation of daughter into a holy woman to keep that land in one hand and consequential dominance. This also shows gender discrimination that continues in one or the other shape.

\section{Acknowledgement:}

The researcher feels grateful to her mentor Dr. Nighat Ahmed for her tremendous knowledge and insights that give guidance. Heartiest thanks to the entire family, especially parents, husband and friends for their constructive comments and support.

\section{References}

Chaturvedi, V. (2000). Mapping subaltern studies and the postcolonial. London and New York: Verso.

Eckert, P., \& Mcconnell-Ginet, S. (2003) Language and Gender. New York, Cambridge University Press. https://doi.org/10.1017/CBO9780511791147

Fairclough, N. (1995). Critical discourse analysis. London: Longman.

Gramsci, A. (1973). Selections from the prison notebooks (ed. by Quintin Hoare and Geoffrey Nowell Smith). New York: International Publishers.

Hooks, B. (1989). Choosing the margin as a space of radical openness from Yearning race, gender, and cultural politics (pp. 203-209). Boston: South End Press. Retrieved from https://sachafrey.files.wordpress.com/2009/11/choosing-the-margin-as-a-space-of-radical-openness-ss-3301 .pdf

Jalal, A. (1996). Secularists, subalterns and the stigma of 'communalism': partition historiography revisited. Modern Asian Studies, 30(3), 681-689. https://doi.org/10.1017/S0026749X00016644

Kharal, A. A. (2007). The holy woman: A feminist perspective. Kashmir Journal of Language Research, 10, $51-$ 64.

Lazar, M. M. (2005). Feminist critical discourse analysis. gender, power and ideology in discourse. London: Palgrave. https://doi.org/10.1057/9780230599901

Lazreg, M. (1988). Feminism and Difference: The Perils of Writing as a Woman on Women in Algeria. Feminist Studies, 14(1), 81-107 https://doi.org/10.2307/3178000

Lewis, R., \& Mills, S. (2003). Feminist Postcolonial Theory; A Reader. USA And Canada: Edinburgh University Press. Retrieved from https://books.google.com.pk/books?id=uYpMo1ZRkMAC\&pg=PA23\&source=gbs_toc_r\&cad=3\#v=onepa ge \&q\&f=false

Maggio, J. (2007). Can the subaltern be heard? Political theory, translation, representation, and gayatri chakravorty spivak. Alternatives, 32, 419-443. https://doi.org/10.1177/030437540703200403

Mohanty, C. T. (2003). Under western eyes: feminist scholarship and colonial discourses. In L. Reina \& M. Sara (Eds.), Feminist postcolonial theory; A reader. USA and Canada: Edinburgh University Press. https://doi.org/10.1215/9780822384649-002

Morton, S. (2003). Gayatri Chakravorty Spivak. London: Routledge. https://doi.org/10.4324/9780203108512

Nelson, C., \& Grossberg, L. (1988). Marxism and the interpretation of culture. Urbana and Chicago: University of Illinois Press. https://doi.org/10.1007/978-1-349-19059-1

Shahraz, Q. (2002). The holy woman. Islamabad: Alhamra Publishing.

Shaw, J. (2005) Critical perspective on Qaisra Shahraz. British Council Literature. Retrieved May 23, 2012, from http://literature.britishcouncil.org/qaisraHshahraz

Siddiqui, M. A. (2011). Interviews to promote The Holy and the Unholy: critical essays on the art and craft of Qaisra Shahraz's fiction. Journal of Solidarity (Pakistan). Retrieved from http://www.transculturalwriting.com/.../11_interview_qaisra_shahraz

Siddiqui, M. A. (2011a). The Political or the social? Qaisra Shahraz and the present Pakistani writings in English. In A. R. Kidwai \& M. A. Siddiqui (Eds.), The Holy and the Unholy: Critical Essays on Qaisra Shahraz's Fiction. New Delhi: Sarup Book Publishers.

Spivak, G. C. (1996). Subaltern talk. In L. Donna \& M. Laudry (Eds.), The Spivak Reader: Selected Works of Gayatri Chakravorty Spivak. New York: Routledge. 
Spivak, G. C. (1988). Can the Subaltern Speak? In N. Cary \& G. Lawrence (Eds.), Marxism and the interpretation of culture. Urbana and Chicago: University of Illinois Press. https://doi.org/10.1007/978-1-349-19059-1_20

Spivak, G. C. (2004). On the cusp of the personal and the impersonal: An Interview with Gayatri Chakravorty Spivak by Laura Lyons and Cynthia Franklin. Biography, 27(1), 203-221. https://doi.org/10.1353/bio.2004.0038

Zine, J. (2006). Between orientalism and fundamentalism: The politics of Muslim women's feminist engagement. Muslim world journal of human rights (Special issue: Post-September 11th Developments in Human Rights in the Muslim World), 3(1). https://doi.org/10.2202/1554-4419.1080

\section{Notes}

Note 1. Izzat: The term is used for the female honor specifically brother, father, husband or son considers their women as their izzat.

Note 2. Purdah: A veil that Muslim women use to cover their face.

Note 3. Ghairat: The men's ego often the term is used in case of women.

Note 4. Burqa: A long shawl that covers the whole body and face.

Note 5. Ressmeh: The rituals and traditions of any culture.

Note 6. Shariah: The teachings of Islam.

\section{Copyrights}

Copyright for this article is retained by the author, with first publication rights granted to the journal.

This is an open-access article distributed under the terms and conditions of the Creative Commons Attribution license (http://creativecommons.org/licenses/by/4.0/). 